\title{
SPATIAL VARIABILITY OF SOIL PHOSPHORUS OF A LOW PRODUCTIVITY Brachiaria brizantha PASTURE
}

\author{
Edemar Joaquim Corazza ${ }^{1}$; Michel Brossard²; Takashi Muraoka ${ }^{1 *}$; Maurício Antonio Coelho \\ Filho $^{3}$ \\ ${ }^{1}$ USP/CENA - Lab. de Fertilidade do Solo, C.P. 96 - 13400-970 - Piracicaba, SP - Brasil. \\ ${ }^{2}$ Embrapa Cerrados - IRD, C.P. 7091 - 71619-970 - Brasília, DF - Brasil. \\ ${ }^{3}$ USP/ESALQ - Depto. de Engenharia Rural, C.P. 9 - 13418-900 - Piracicaba, SP - Brasil. \\ *Corresponding author <muraoka@cena.usp.br>
}

\begin{abstract}
Studies on soil phosphorus (P) of low productivity cultivated pastures in Cerrado (Brazilian Savanna) areas and surveys on other possible problems related to $\mathrm{P}$ are scarce. The spatial variability of soil phosphorus content of a Rhodic Ferralsol was studied in a low productivity pasture of Brachiaria brizantha $(\mathrm{BB})$ grown for 10 years, without fertilizer application, in an experimental area at Planaltina (GO), Brazil. Soil samplings were performed on a regular grid of 10 by 10 meters, with 98 sampling points before (between tussocks and under tussocks) and after the establishment of the experiment (after fertilizing). On the same grid, forage plants were collected and separated into fractions for $\mathrm{N}$ and $\mathrm{P}$ content analyses. Soil available phosphate was determined by the resin method $\left(\mathrm{P}_{\mathrm{r}}\right)$ and complemented by the ${ }^{32} \mathrm{P}$ isotopic exchange kinetics analysis. Descriptive statistical and geostatistical analyses were utilized to describe the spatial variability. The $P_{r}$ content on soil samples under tussocks presented mean and median values $45 \%$ larger than in soil samples taken between tussocks. The higher variation is probably related to the greater concentration of BB roots, soil organic matter content and soil P recycled through the plants tussocks. The spatial variability of $\mathrm{P}_{\mathrm{r}}$ in this soil was high especially after fertilizer application. This variable did not present spatial dependence for the regular $10 \mathrm{~m}$ sampling. The generated knowledge on $\mathrm{P}$ variability of soils under low productivity cultivated pastures revealed problems related to the sampling methodology traditionally utilized and to $\mathrm{P}$ application.
\end{abstract}

Key words: resin-extractable $\mathrm{P}$, fertilization, tussock, isotopic exchange kinetics, phosphate

\section{VARIABILIDADE ESPACIAL DO FÓSFORO DE SOLO SOB PASTAGEM DE Brachiaria brizantha DE BAIXA PRODUTIVIDADE}

\begin{abstract}
RESUMO: A falta de dados de campo sobre o fósforo (P) do solo sob pastagens cultivadas de baixa produtividade na Região do Cerrado e o levantamento de outros possíveis problemas ligados ao $\mathrm{P}$ motivaram o presente trabalho. Estudou-se a variabilidade espacial do fósforo de um Latossolo Vermelho cultivado por 10 anos com Brachiaria brizantha (BB), sem aplicação de fertilizantes, em área experimental localizada em Planaltina (GO). A amostragem do solo foi realizada em malha sistemática de 10 em 10 metros, em 98 pontos, antes (entre touceiras e sob touceira) e depois da implantação do experimento (após fertilização). A gramínea forrageira também foi coletada e separada em frações para a determinação dos teores de $\mathrm{N}$ e P. O conteúdo do $\mathrm{P}$ no solo foi determinado pelo método de resina $\left(\mathrm{P}_{\mathrm{r}}\right)$ e complementado por análises de cinética de troca isotópica $\operatorname{com}^{32} \mathrm{P}$. A descrição da variabilidade espacial foi realizada por meio de análises estatística descritiva e geoestatística. As amostras sob touceiras apresentaram médias e medianas de P $45 \%$ superiores entre touceiras, provavelmente associada à maior concentração do sistema radicular da $\mathrm{BB}$, maior conteúdo de matéria orgânica do solo e da reciclagem do $P$ via touceira da planta. A variabilidade espacial do $P_{r}$ foi alta principalmente após a aplicação do fertilizante. Essa variável não apresentou dependência espacial para uma amostragem regular de 10 metros. O conhecimento da variabilidade do $\mathrm{P}$ em solos sob pastagens cultivadas de baixa produtividade revelou problemas relacionados à metodologia de amostragem tradicionalmente utilizada e à aplicação do fertilizante realizada.

Palavras-chave: P-resina, fertilização, touceira, cinética de troca isotópica, fosfato
\end{abstract}

\section{INTRODUCTION}

In the Cerrado Region (Brazil) cultivated pastures (i.e. Brachiaria spp.) represent 49.5 million ha (Sano et al., 2000) and approximately $80 \%$ of which present low productivity (Kluthcouski et al., 1999). Inadequate pasture management, overgrazing, and the lack of maintenance fertilization are pointed as causes for decline yield. 
The reduction in areas of natural vegetation destined to opening and establishing pastures and, conversely, the growing pressure for the conservation of non-renewable natural resources and the development of technologies for better exploration of areas previously grown as pastures, have contributed to an increased interest on cultivated pastures. Priority should be given to guidelines for management that would allow the reclamation of areas in early stages of decline or already degraded, instead of simply encouraging expansion of the agro-silvo-pastoral front according to the occupation models that have occurred so far (Lopes, 1997).

The reclamation of cultivated pastures presumes a knowledge on soil fertility fluctuations through soil analyses. The greatest interest usually refers to P content, since it is one of the most limiting nutrients for the production of forage plants. In addition, $\mathrm{P}$ inputs have high costs in Brazil. Even though it is generally thought that the $\mathrm{P}$ variability is low and that it is not necessary to gather information on it to begin a pasture reclamation strategy. The variability of $\mathrm{P}$ contents in pastures depends on the management. Replacing natural vegetation with the forage plant, soil tillage, liming and fertilizing with $\mathrm{P}$ at pasture establishment are some management practices that influence soil phosphorus variability. In addition, the irregular return of manure and urine (spatial and temporal) to the pasture (Petersen et al., 1956a, b), combined with reduced soil tillage and cultivation as compared to soils that are annually tilled, create a potential for considerable development of soil heterogeneity with respect to nutrient concentration (Fisher et al., 1998).

The heterogeneous supply of nutrients in the soil results in plant growth at various scales. Within the space of a defined root system, the proliferation of roots and the increase in the rate of $\mathrm{P}$ absorption occurs as a response to sites that have been enriched by the addition of P (Jackson et al., 1990). At field scale, soil heterogeneity contributes to species coexistence in pastures, through a variety of different niches where plant species compete individually with greater success (Reynolds et al., 1997). Also at field scale, soil heterogeneity per se is considered to favor plant communities locally when compared with isolated plants (Birch \& Hutchings, 1994). In a superior scale of individual root systems, the exchangeable $\mathrm{P}$ in the soil is related to the distribution of many plants (Tyler, 1996).

A knowledge of phosphorus spatial variability in soils under pasture is essential to establish adequate reclamation strategies. Some authors have reported extremely low phosphorus levels in soils under low productivity pastures (Oberson et al., 1999). However, those results refer to composite samples collected in the pastures, not to systematic surveys devised to check for phosphorus variability and other soil physical and chemical attributes.
A literature review on this subject reveals that field data on phosphorus in soils under degraded or low productivity pastures in the Cerrado Region are scarce. This work is, therefore, an attempt to evaluate the spatial variability of soil phosphorus in a Brachiaria brizantha $\mathrm{cv}$. Marandu (BB) low productivity pasture, identifying the distribution of soil phosphorus contents and their possible relations with the Brachiaria brizantha.

\section{MATERIAL AND METHODS}

The present work was carried out on a 29.11 ha experimental area at Planaltina-GO, Brazil $\left(15^{\circ} 27^{\prime} 10^{\prime \prime} \mathrm{S}\right.$ and $47^{\circ} 36^{\prime} 51^{\prime \prime} \mathrm{W}$ ), altitude $826 \mathrm{~m}$. The Brachiaria brizantha cv. Marandu (BB) grass, introduced in 1990 after the native vegetation was cleared. The BB carrying capacity during the rainy season was lower than 1 animal unit (AU) ha ${ }^{-1}(\mathrm{AU}=450 \mathrm{~kg}$ live weight). The little live weight gain in the rainy season and the live weight loss in the dry season characterized the low yield capacity per animal and per hectare of this pasture. The area was selected for the installation of an experiment to study pasture reclamation under grazing. Dolomitic lime $3 \mathrm{tha}^{-1}$ have been applied at soil surface. The mean results of 10 soil samples collected from the $0-10 \mathrm{~cm}$ layer on a Rhodic Ferralsol were as follows: clay $=800 \mathrm{~g} \mathrm{~kg}^{-1} ; \mathrm{pH} \mathrm{H}_{2} \mathrm{O}=$ 5.9; $\mathrm{P}\left(\right.$ Mehlich-1) $=0.3 \mathrm{mg} \mathrm{L}^{-1}$; organic matter $=28 \mathrm{~g}$ $\mathrm{kg}^{-1}$; cation exchange capacity $=99 \mathrm{mmol}_{\mathrm{c}} \mathrm{kg}^{-1}$, and base saturation $=50 \%$.

Planimetric and altimetric surveys and spatial location of trees, remainder pile and fences preceded the subdivision of the area into six plots of 4.9 ha each for the installation of the following treatments, in February 1999: i) control; ii) $40 \mathrm{~kg} \mathrm{ha}^{-1} \mathrm{P}$ as Gafsa reactive phosphate (GRP) (T2); iii) ditto as T2 with the introduction of Stylosanthes guianensis cv. Mineirão (SG) (T3); iv) $80 \mathrm{~kg} \mathrm{ha}^{-1} \mathrm{P}$ as GRP (T4); v) $40 \mathrm{~kg} \mathrm{ha}^{-1} \mathrm{P}$ as triple superphosphate (TSP) (T5); and vi) ditto as T5 with the introduction of SG (T6). The areas were subsequently divided into four paddocks for animal rotation (P1, P2, P3, P4 Figure 1a). Phosphates were applied to the surface and incorporated to $\pm 10 \mathrm{~cm}$ with heavy harrow.

Single soil samples were collected with an auger from September to October 1998 before installation of the experiment. Collections were made on 54 points at depths 0-10, $10-20$ and $20-30 \mathrm{~cm}$, equidistant $40 \mathrm{~m}$, in the five rows of the treatment divisors (Figure 1a), W-E direction, to evaluate $\mathrm{P}$ variability in the total area of the experiment. A probability drawing was performed on the selected treatments (T6) and paddock two (P2). This area was located $70 \mathrm{~m}$ in the S-N direction, and $140 \mathrm{~m}$ in the W-E direction and marked with stakes on a 10 by $10 \mathrm{~m}$ grid design, with 98 sampling points, a total area of $9,800 \mathrm{~m}^{2}$ (Figure $1 \mathrm{~b}$ ). The ascending direction of the slope runs in the direction of the coordinate y from 0 to 
$130 \mathrm{~m}$, with $\pm 5 \%$ slope. In the marked row there is a remainder pile that was built by piling up vegetation stubble when the area was deforested and then burned. At the 98 points, single soil samples were collected from the surface layer $(0-10 \mathrm{~cm})$ between tussocks, and under tussocks. At the same location, a $0.5 \mathrm{~m}^{2}$ area of $\mathrm{BB}$ was collected by cutting at ground level and separated botanically and into fractions of BB as green matter (GM), dry matter (DM) and litter (L) on a dry weight basis; P content was determined in samples consisting of each row of the y coordinate, except for remainder pile samples. In September 1999, after the installation of the experiment, soil samples were collected at the same previously sampled points, in addition to another 24 points sampled on a $2.5 \times 2.5 \mathrm{~m}$ grid marked with small crosses (Figure 1b) to evaluate the effect of TSP application on soil P variability. In addition, 30 simple random soil samples under adjacent native vegetation (cerrado) were collected to constitute 3 composite samples.

Available phosphorus $\left(\mathrm{P}_{\mathrm{r}}\right)$ was colorimetrically determined by the resin method (Raij et al., 1986). Total $\mathrm{P}$ contents in the plant were determined by colorimetry after wet digestion with perchloric acid and peroxide (Adler \& Wilcox, 1985).

The isotopic exchange kinetics (IEK) analyses were performed in the soil solution system after the samples had reached equilibrium in a 1:10 soil-solution ratio (Salcedo et al., 1991; Fardeau et al., 1991; Frossard

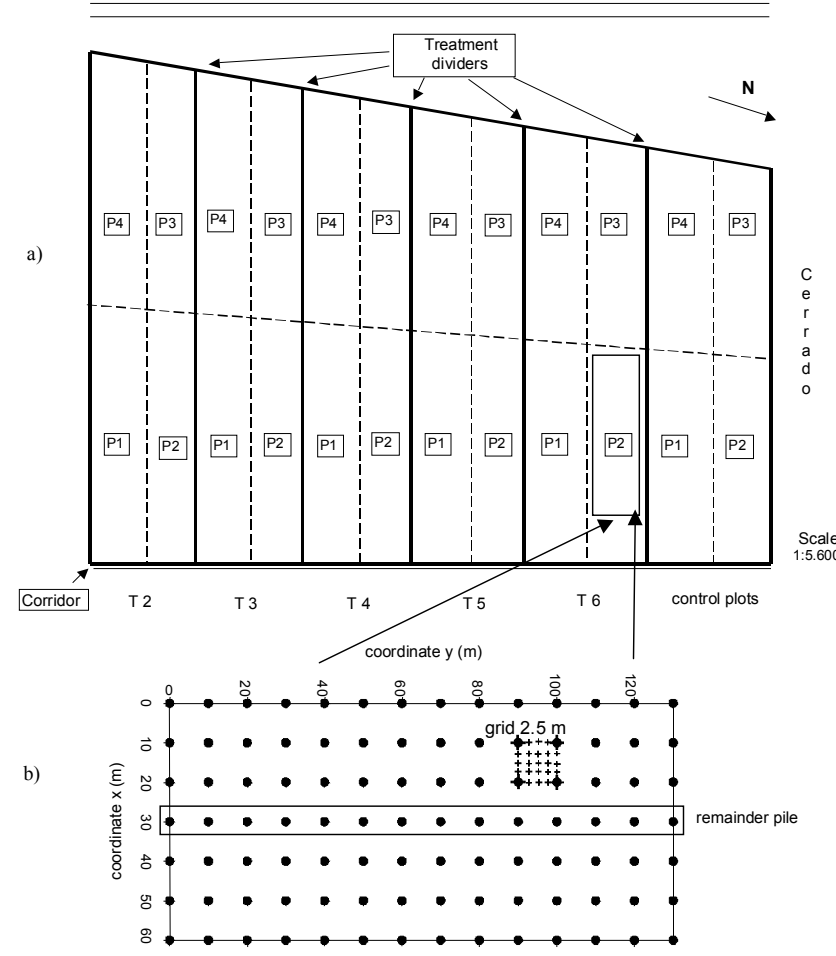

Figure 1 - a) Schematics of the experimental area with treatments and corresponding paddock subdivisions. b) Spatial distribution of the 98 sampling points in the experiment area. Selected at random in T6 P2. et al., 1994). The system consisted of $10 \mathrm{~g}$ soil, sifted through a $2 \mathrm{~mm}$ mesh sieve, and $99 \mathrm{~mL}$ deionized water in a $250 \mathrm{~mL}$ capacity plastic container. Samples were stirred for 16 hours and then placed over a magnetic stirrer, and $1 \mathrm{~mL}$ of a solution containing carrier-free ${ }^{32} \mathrm{P}$ radioisotope, with an activity of approximately 1 Megabecquerel $\mathrm{mL}^{-1}$, was added at time zero $(\mathrm{t}=0)$. After $\mathrm{t}_{1}=1, \mathrm{t}_{2}=3, \mathrm{t}_{3}=10$ and $\mathrm{t}_{4}=15 \mathrm{~min}$, an aliquot of $\pm 8 \mathrm{~mL}$ of the suspension was drawn with a plastic syringe, which was immediately connected to a pressure filter holder with a $0.05 \mu \mathrm{m}$ membrane filter. The suspension was filtered in \pm 10 seconds and a $0.25 \mu \mathrm{L}$ aliquot was removed with a micro pipet; the volume was completed to $20 \mathrm{~mL}$ for later determination of the ${ }^{32} \mathrm{P}$ counts by Cerenkov effect in a liquid scintillation counter. At the end of the process, $60 \mathrm{~mL}$ syringes were utilized to obtain a larger amount of solution to determine the concentration of phosphate $(\mathrm{Cp})$ present in the soil solution by colorimetry through the malachite green method (Rao et al., 1997). The concentration of phosphate ions in the filtered solution was determined with $3 \times 2 \mathrm{~cm}$ membranetype anionic resin pieces (BDH15 1TD) as recommended by Salcedo et al. (1991). The obtained soil solution phosphate concentration values of a standard sample had a $1.23 \%$ coefficient of variation $(\mathrm{CV} ; \mathrm{n}=3)$.

Two statistical analyses procedures were utilized. The first consisted of a general descriptive analysis of the results and correlations between soil $\mathrm{P}$ and plant variables, performed with the Statistica for Windows Statsoft (1996) software package. The second corresponded to a spatial continuity study of the variables under consideration. This study was preceded by an exploratory analysis of data including a median refinement (Hamlett et al., 1986) to remove the large scale variation effect (trend) of variable $P$ in the experimental area. Spatial dependence was studied by semivariograms obtained from the collected samples and analyzed with the Variowin 2.2 (Pannatier, 1996) software package.

\section{RESULTS AND DISCUSSION}

The $\mathrm{P}_{\mathrm{r}}$ contents of the treatment divider were between 1 and $9 \mathrm{mg} \mathrm{kg}^{-1}$, minimum and maximum values, respectively (Figure 2). The widest amplitude was found for the $0-10 \mathrm{~cm}$ depth. $\mathrm{P}_{\mathrm{r}}$ contents decreased with depth, as expected; the decline, however, was not abrupt. The spatial dependence study revealed that spatial continuity did not exist for the 54 samples from the $40 \mathrm{~m}$ spaced divisors.

The construction of $\mathrm{P}_{\mathrm{r}}$ semivariograms of soil samples between tussocks and after fertilizing $(10 \mathrm{~m}$ grid), indicated no space variation structure. Spatial independence was also verified when the same data were analyzed and samples located on the remainder pile line (Figure 1b); values on average higher than in other points, 
were disregarded. However, for samples collected under tussocks, a decreasing tendency was observed for P values in the ascending direction of the slope (Figure 3a), which was also reflected in the semivariogram that corresponds to the original data (Figure 3b), a tendency of indefinite growth being observed, indicating that an intrinsic stationarity, a model assumption in any geostatistical study, was not met.

The semivariogram of refinement residues (Figure 3b) for $\mathrm{P}_{\mathrm{r}}$ under tussocks indicates that this variable does not present a spatial dependence structure (pure nugget effect). The growth tendency of $\mathrm{P}_{\mathrm{r}}$ contents in the descend-

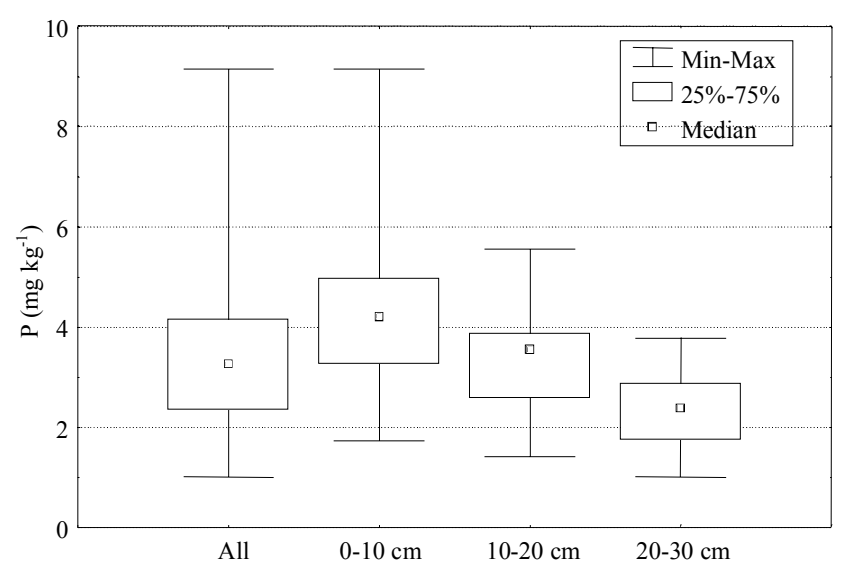

Figure 2 - Box-plots of $\mathrm{P}$ contents evaluated by the resin method in the treatments divisions.
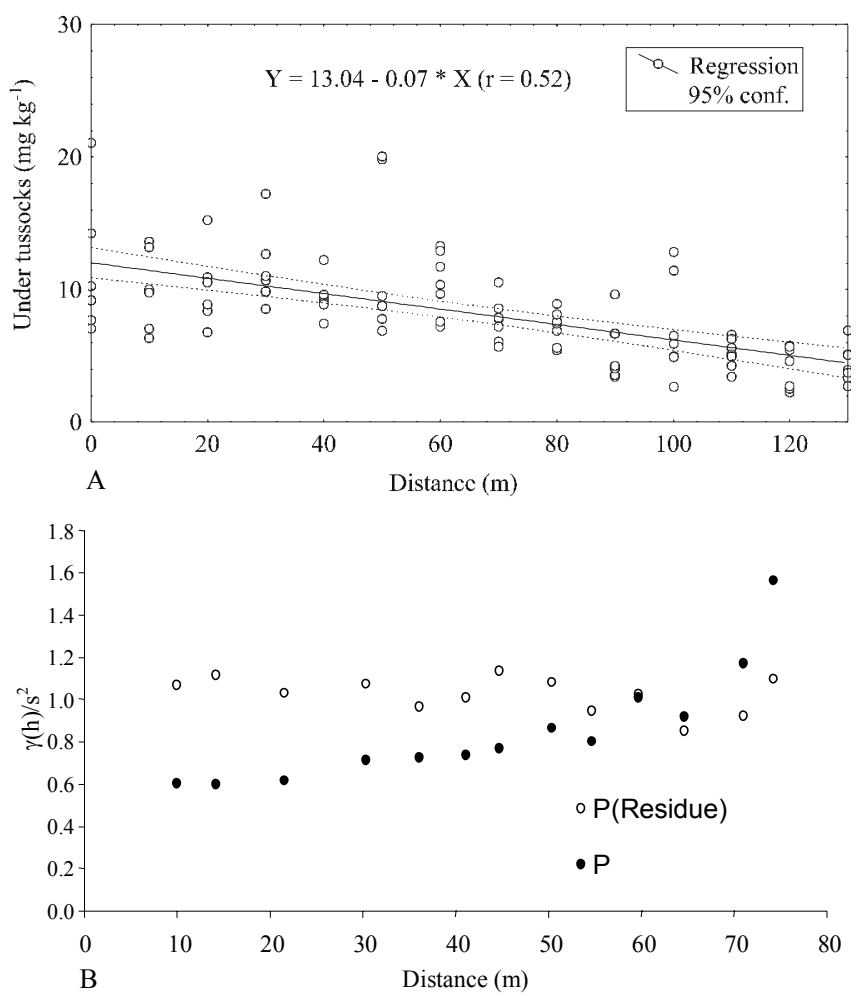

Figure 3 - Correlation of phosphorus $\left(\mathrm{P}_{\mathrm{r}}\right)$ with slope $(\mathrm{a})$ and scaled semivariograms of the original data and residues (b) for $\mathrm{P}_{\mathrm{r}}$ under tussocks. ing direction of the slope verified in the original data was efficiently removed through median refinement. Overall, no spatial dependence exists for the sampled distance (10 x 10 m systematic grid) of variables $P_{r}$ in the soil between tussocks, under tussocks and after fertilizing. As performed, sampling was not sufficient to detect spatial dependence.

Distinct situations were observed in the comparison of $\mathrm{P}_{\mathrm{r}}$ between tussocks and under tussocks (Figure 4): Samples between tussocks had smaller means and medians than those under tussocks, approximately $45 \%$ lower. Even though the minimum values are close, the maximum was approximately fourfold greater under tussocks (Figure 4), demonstrating greater variation of the data (amplitude, variance and standard deviation), at least twice as high as the values for samples between tussocks. This greater variation in $\mathrm{P}$ contents $\mathrm{CV}$ between tussocks $=29 \%$ and under tussocks $=62 \%$ ) is probably related to the greater concentration of the root system and to P cycling via litter in these samples. The observation of soil profiles in the experimental area had a poorer distribution of roots between tussocks, even when soil conditions under tussocks presented physical properties that would limit root system development. With regard to litter, it is worth noting that at the time of sampling the soil was bare between tussocks and the litter was under the tussocks.

The construction of a correlation matrix to evaluate the relationship between soil $\mathrm{P}_{\mathrm{r}}$ and plant $\mathrm{P}$ did not indicate correlation of $\mathrm{P}_{\mathrm{r}}$ between tussocks and $\mathrm{P}$ in the GM, DM and L (Figure 5a). However, linear correlations were found between $\mathrm{P}_{\mathrm{r}}$ under tussocks and plant $\mathrm{P}$ (Figure 5b) $(P=0.0006)$. These results confirmed a differentiated exploration of the soil between tussocks and under the tussocks, probably connected to the heterogeneous distribution of the BB root system as observed in the soil profiles. The proliferation of roots and the increase in forage-absorbed $\mathrm{P}$ occurs as a response to microlocations rich in P supply (Jackson et al., 1990). In this work, the nine-year-old plant-tussock system contributed to increas-

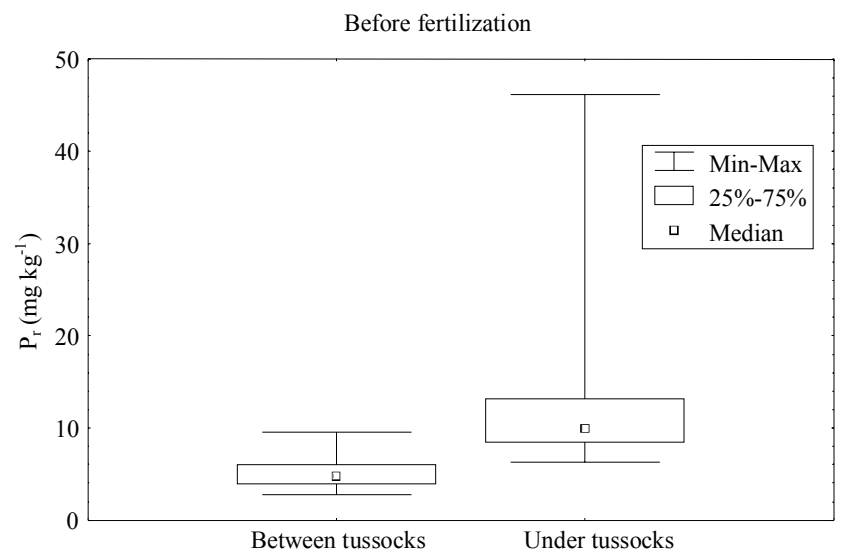

Figure 4 - Box-plot of phosphorus contents $\left(\mathrm{P}_{\mathrm{r}}\right)$ between tussocks and under tussocks before fertilization in the $10 \mathrm{~m}$ grid considering all sampling points. 
ing P supply, what can be explained by the recycling via litter. The DM and $\mathrm{L}$ evaluation after a stockpiling forage period of \pm 1 year represented $1.5 \mathrm{~kg} \mathrm{ha}^{-1} \mathrm{P}( \pm 0.5)$.

The $\mathrm{P}$ buffering capacity of the soil $\left(\mathrm{R} / \mathrm{r}_{1}\right)$ for samples between tussocks was greater than in the cerrado, the remainder pile and under tussocks (Table 1), corroborating to the $\mathrm{P}_{\mathrm{r}}$ results shown in Figures $4 \mathrm{a}$ and 6 . These results demonstrated that differences in $\mathrm{P}$ bioavailability exist between tussocks and under tussocks in this low productivity pasture. Similar results were obtained by Fisher et al. (1998) and Cross \& Schlesinger (2001). Organic matter should probably contribute to these results (Mesquita Filho \& Torrent, 1993; McDowell \& Sharpley, 2001) and possibly litter cycling plays a role as well.

Therefore, if sampling was to be performed under tussocks, P bioavailability would not be limiting, on average, to pasture development, while between tussocks it would be limiting according to the resin methodology (Vilela et al., 2000). In an experiment conducted in the same location and in a greenhouse with soil from the area, positive responses were observed for phosphate fertilization. These contradictory results of soil sampling location denote the necessity of future research to shed additional light on the dynamics of $\mathrm{P}$ cycling within a system of low productivity pasture, under the tussocks and between tussocks, in a community of plants; some not yet known aspects of $\mathrm{P}$ cycling might therefore be elucidated.

$\mathrm{P}_{\mathrm{r}}$ determinations after fertilizer application were sixfold higher for the median (26.5 mg kg $\left.\mathrm{mg}^{-1}\right)$ and 10-fold higher for the mean (47.4 $\mathrm{mg} \mathrm{kg}^{-1}$ ) as compared to $\mathrm{P}_{\mathrm{r}}$ between tussocks (Figure 7). Variability increased significantly with CV jumping from 29 to 120 and $71 \%$ after fertilizing, in the 10 and $2.5 \mathrm{~m}$ grids, respectively. The $\mathrm{P}_{\mathrm{r}}$ minimum values were near those observed before the application of fertilizers, demonstrating that fertilization was not made at those locations. The maximum values are well above the expected and occurred in areas where fertilizers were applied in excess. Fertilizer pellets that had not yet been dissolved were found in some soil samples. The sam- pling results of the $2.5 \mathrm{~m}$ grid (Figure 7) are lower than the median $\left(15.8 \mathrm{mg} \mathrm{kg}^{-1}\right)$ and the mean $\left(19.7 \mathrm{mg} \mathrm{kg}^{-1}\right)$ as compared to the sampling of the $10 \mathrm{~m}$ grid. This reflects a localized condition that might have been influenced by a non-uniform application of $\mathrm{P}$ in the experimental area, which also favored greater sampling variability in the entire area represented by the $10 \mathrm{~m}$ grid. This also reflects the non-stationarity of the mean because of the previously verified tendency, in which a decrease in $\mathrm{P}_{\mathrm{r}}$ values occurs under tussocks in the ascending direction of the slope.
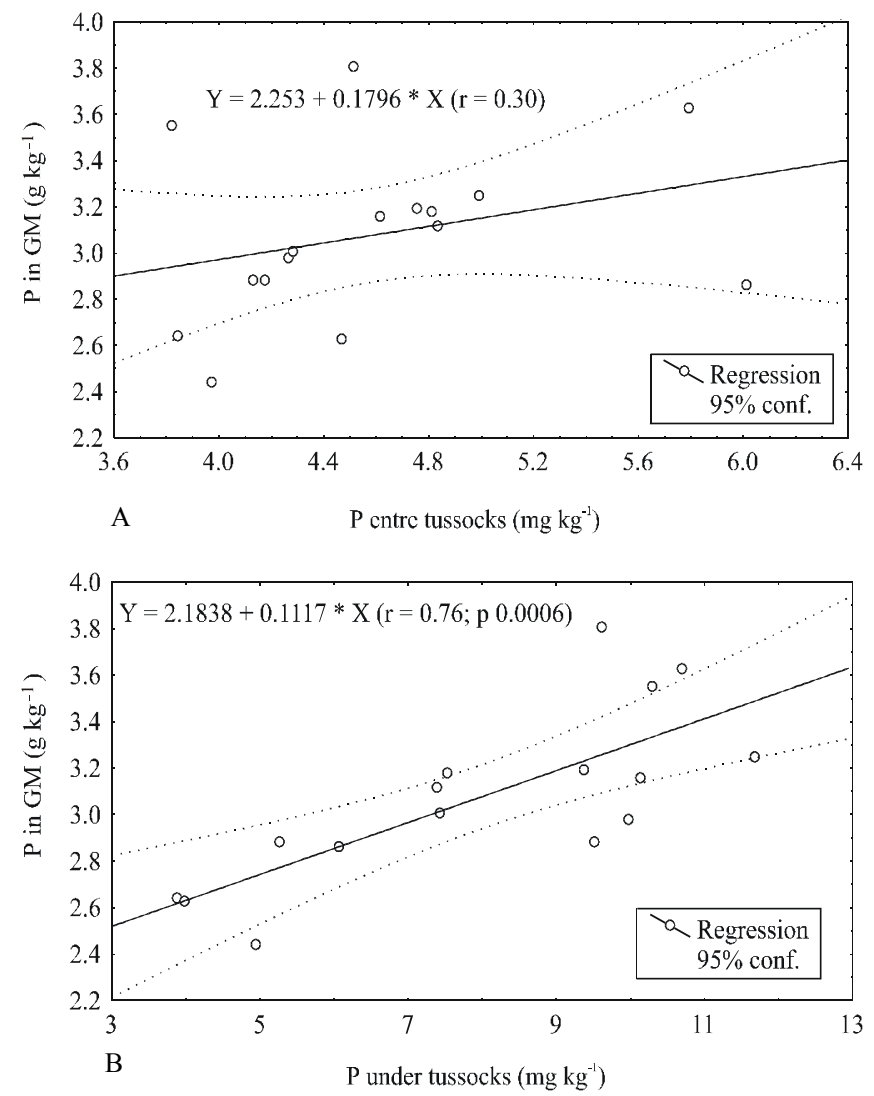

Figure 5 - Correlations between available phosphorus $\left(\mathrm{P}_{\mathrm{r}}\right)$ between tussocks (a) and at the tussocks (b) with green matter phosphorus (GM) of Brachiaria brizantha.

Table 1 - Soil buffer power $\left(\mathrm{R} / \mathrm{r}_{1}\right)$, concentration of phosphate ions in soil solution $(\mathrm{Cp})$, linear slope $(\mathrm{n})$, total $\mathrm{P}(\mathrm{Pt})$, and organic $\mathrm{P}(\mathrm{Po})$ of compound samples per treatment.

\begin{tabular}{|c|c|c|c|c|c|}
\hline Treatment & $\mathrm{R} / \mathrm{r}_{1}$ & $\mathrm{Cp}$ & $\mathrm{n}$ & $\mathrm{Pt}$ & Po \\
\hline & - & -- $\mathrm{mg} \mathrm{L}^{-1}$ & - & - & - \\
\hline Cerrado & 3070 & 0.0014 & 0.353 & 279 & 130 \\
\hline $\mathrm{sd}^{1}$ & (1002) & $(0.0003)$ & $(0.014)$ & (24) & (55) \\
\hline Between tussocks & 6980 & $\mathrm{na}^{2}$ & 0.718 & 376 & 201 \\
\hline sd & (1208) & & $(0.009)$ & (12) & (5) \\
\hline Remainder pile & 2401 & na & 0.591 & 409 & 280 \\
\hline sd & (681) & & $(0.076)$ & (37) & (34) \\
\hline Under tussocks & 454 & 0.0030 & 0.422 & 491 & 206 \\
\hline sd & (150) & $(0.0023)$ & $(0.047)$ & (36) & (81) \\
\hline
\end{tabular}

${ }^{1} \mathrm{sd}=$ standard deviation, results between parentheses in rows; ${ }^{2} \mathrm{na}=$ not analyzed. 


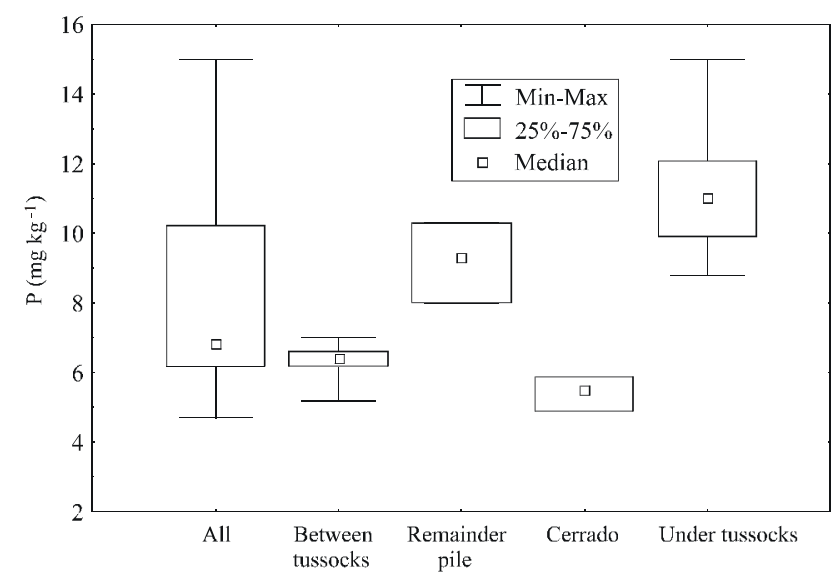

Figure 6 - Box-plot of $\mathrm{P}$ contents $\left(\mathrm{P}_{\mathrm{r}}\right)$ in composite samples collected before the installation of the experiment and in an adjacent cerrado area.

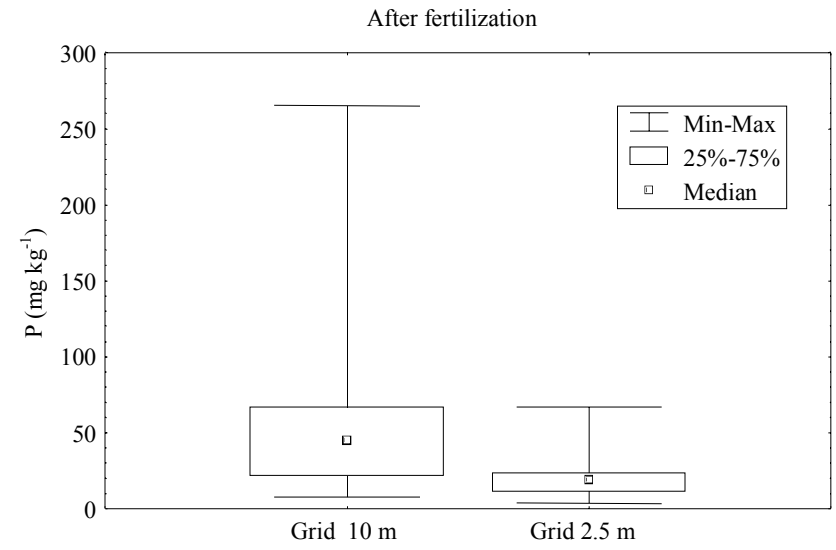

Figure 7 - Box-plot of available phosphorus contents $\left(\mathrm{P}_{\mathrm{r}}\right)$ after fertilizing in $10 \mathrm{~m}$ and $2.5 \mathrm{~m}$ sampling grids considering all sampling points.

\section{CONCLUSIONS}

The employed sampling method was not sufficient to characterize the spatial dependence of $\mathrm{P}$ in the soil. The bioavailability of $\mathrm{P}$ of the soil under a low productivity Brachiaria brizantha pasture is directly related to the structure of the tussock units. Therefore, this is an indication that soil sampling for $\mathrm{P}$ bioavailability evaluation in these pastures can be performed under the tussocks.

\section{ACKNOWLEDGEMENT}

To IRD (Institut de Recherche pour le Développement) for the scholarship to the first author and to IRD, Embrapa Cerrados and CENA for the financial support.

\section{REFERENCES}

ADLER, P.R.; WILCOX, G.E. Rapid perchloric acid digest methods for analysis of major elements in plant tissue. Communications in Soil Science and Plant Analysis, v.16, p.1153-1163, 1985.

BIRCH, C.P.D.; HUTCHINGS, M.J. Exploitation of patchily distributed soil resources by the clonal herb Gleuchoma hederacea. Journal of Ecology, v.82, p.653-664, 1994.
CROSS, A.F.; SCHLESINGER, W.H. Biological and geochemical controls on phosphorus fractions in semiarid soils. Biogeochemistry, v.52, p.155-172, 2001.

FARDEAU, J.C.; MOREL, C.; BONIFACE, R. Cinétiques de transferts des ions phosphate du sol vers la solution du sol: paramètres caractéristiques. Agronomie, v.11, p.787-797, 1991.

FISHER, E.; THORNTON, B.; HUDSON, G.; EDWARDS, A.C. The variability in total and extractable soil phosphorus under a grazed pasture. Plant and Soil, v.203, p.249-255, 1998.

FROSSARD, E.; FARDEAU, J.C.; BROSSARD, M.; MOREL, J.L. Soil isotopically exchanbeable phosphorus: A comparison between $\mathrm{E}$ and $\mathrm{L}$ values. Soil Science Society of America Journal, v.58, p.846-851, 1994.

HAMLETT, J.M.; HORTON, R.; CRESSIE, N.A.C. Resistant and exploratory techniques for use in semivariogram analyses. Soil Science Society of America Journal, v.50, p.868-875, 1986.

JACKSON, R.B.; MANWARING, J.H.; CALDWELL, M.M. Rapid physiological adjustment of roots to localized soil enrichment. Nature, v.344, p.58-60, 1990.

KLUTHCOUSKI, J.; OLIVEIRA, I.P.; YOKOYAMA, L.P.; DUTRA, L.G.; PORTES, T.A.; SILVA, A.E.; PINHEIRO, B.S.; FERREIRA, E.; CASTRO, E.M.; GUIMARÃES, C.M.; GOMIDE, J.C.; BALBINO, L.C. Sistema Barreirão: recuperación/renovación de pasturas degradadas utilizando cultivos anuales. In: GUIMARÃES, E.P.; SANS, J.I.; RAO, I.M.; AMÉZQUITA, M.C.; AMÉSQUITA, E. (Ed.) Sistemas agropastoriles en sabanas tropicales de America Latina. Cali: CIAT; Brasília: Embrapa, 1999. cap.15, p.195-231.

LOPES, A.S. Diretrizes para o manejo sustentável dos solos brasileiros região dos Cerrados. In: CONGRESSO BRASILEIRO DE CIÊNCIA DO SOLO, 26., Rio de Janeiro, 1997. Informação, globalização, uso do solo; anais. Rio de Janeiro: SBCS, 1997. p.65-80.

McDOWELL, R.W.; SHARPLEY, A.N. Soil phosphorus fractions in solution: influence of fertiliser and manure, filtration and method of determination. Chemosphere, v.45, p.737-748, 2001.

MESQUITA FILHO, M.V.; TORRENT, J. Phosphate sorption as related to mineralogy of a hydrosequence of soils from the cerrado region (Brazil). Geoderma, v.58, p.107-123, 1993.

OBERSON, A.; FRIESEN, D.K.; TIESSEN, H.; MOREL, C.; STAHEL, W. Phosphorus status and cycling in native savanna and improved pastures on an acid low-P Colombian Oxisol. Nutrient Cycling in Agroecosystems, v.55, p.77-88, 1999.

PANNATIER, Y. Variowin: software for spatial data analysis in 2D, V.2.2. New York: Springer-Verlag, 1996. 93p.

PETERSEN, R.G.; LUCAS, H.L.; WOODHOUSE, W.W. The distribution of excreta by freely grazing cattle and its effect on pasture fertility: I. Excretol distribution. Agronomy Journal, v.48, p.440-444, 1956a.

PETERSEN, R.G.; WOODHOUSE, W.W.; LUCAS, H.L. The distribution of excreta by freely grazing cattle and its effect on pasture fertility: II. Effect of returned excreta on the residual concentration of some fertilizer elements. Agronomy Journal, v.48, p.444-449, 1956b.

RAIJ, B. van; QUAGGIO, J.A.; SILVA, N.M. Extraction of phosphorus, potassium, calcium and magnesium from soils by an ion-exchange resin procedure. Communications in Soil Science and Plant Analysis, v.17, p.544-566, 1986.

RAO, A.S.; REDDY, K.S.; TAKKAR, P.N. Malachite green method compared to ascorbic acid for estimating small amounts of phosphorus in water, $0.01 \mathrm{M}$ calcium chloride, and Olsen soil extracts. Communications in Soil Science and Plant Analysis, v.28, p.589-601, 1997.

REYNOLDS, H.L.; HUNGATE, B.A.; CHAPIN III, F.S.; D'ANTONIO, C.M. Soil heterogeneity and plant competition in an annual grassland. Journal of Ecology, v.78, p.2076-2090, 1997.

SALCEDO, I.H.; BERTINO, F.; SAMPAIO, E.V.S.B. Reactivity of phosphorus in Northeastern Brazilian soils assessed by isotopic dilution. Soil Science Society of America Journal, v.55, p.140-145, 1991.

SANO, E.E.; BARCELLOS, A.O.; BEZERRA, H.S. Assessing the spatial distribution of cultivated pastures in the Brazilian savanna. Pasturas Tropicales, v.22, p.2-15, 2000.

STATSOFT. Statistica for windows V.6.0. Tulsa: Statsoft, 1996.

TYLER, G. Cover distributions of vascular plants in relation to soil chemistry and soil depth in a granite rock ecosystem. Vegetatio, v.127, p.215-223, 1996.

VILELA, L.; SOARES, W.V.; SOUSA, D.M.G.; MACEDO, M.C.M. Calagem e adubação para pastagens na região do cerrado. Planaltina: Embrapa Cerrados, 2000. 15p. (Circular Técnica, 37).

Received May 07, 2002

Accepted April 16, 2003 